\title{
First report of phytoplasma 'Candidatus Phytoplasma trifolif' (16Sr VI) group associated with leaf yellows of Calotropis gigantea in India
}

\author{
M. Priya ${ }^{1}$, Y. Chaturvedi ${ }^{1}$, G.P. Rao ${ }^{1 *}$ and S.K. Raj $^{2}$ \\ ${ }^{1}$ Sugarcane Research Station, Kunraghat, Gorakhpur 273 008, UP, India.; ${ }^{2}$ Plant Virology Laboratory, National Botanical \\ Research Institute, Lucknow- 226001, UP, India
}

*E-mail: gprao_gor@rediffmail.com

Received: 19 Jul 2010. Published: 01 Nov 2010

Calotropis gigantea(family Asclepiadaceae), commonly known as milkweed, is a common wasteland weed. It is traditionally used in India to treat fevers, rheumatism, indigestion, cough, cold, eczema, asthma, elephantiasis, nausea, vomiting and diarrhoea. Symptoms of severe leaf yellowing were noticed on $C$. gigantea plants (Fig. 1) growing widely along the roadsides at Gorakhpur, Uttar Pradesh, India during January 2010. To investigate the possibility of phytoplasma infection, total DNA was isolated from leaf tissues of infected and healthy $C$. gigantea plants using the phytoplasma enrichment procedure (Ahrens \& Seemüller, 1992). Nested PCR was performed using universal primers specific to the phytoplasma 16S rRNA gene: P1/P6 (Deng \& Hiruki, 1991) and R16F2n/R16R2 (Gundersen \& Lee, 1996). Expected size amplicons of $\sim 1.5 \mathrm{~kb}$ and $\sim 1.2 \mathrm{~kb}$, respectively, were obtained from infected samples $(2 / 2)$ but not from healthy plants. The amplicon of $\sim 1.2 \mathrm{~kb}$ was eluted through the PCR Clean-up System (Promega, USA) and ligated into pGEM-T Easy Vector System (Promega, USA). Two clones were sequenced and the consensus sequence data of both clones were deposited in GenBank (Accession No. HM485690). BLAST analysis of the partial $16 \mathrm{~S}$ rDNA sequence of the C. gigantea phytoplasma (HM485690) revealed the highest sequence identity (99\%) with that of the Datura inoxia phytoplasma (EU573925), a member of the ' $\mathrm{Ca}$. Phytoplasma trifolii' (16SrVI) group (Raj et al., 2009). Phylogenetic analysis of the $C$. gigantea phytoplasma $16 \mathrm{~S}$ rDNA sequence with those of $16 \mathrm{SrVI}$ phytoplasma isolates and other phytoplasma groups (MEGA version 4.0) revealed its closest phylogenetic relationship with members of the $16 \mathrm{SrVI}$ group (Fig. 2).The $C$. gigantea phytoplasma was identified as a 'Ca. Phytoplasma trifolii' (16SrVI) isolate.

The results suggest that $C$. gigantea may be a reservoir for ' $\mathrm{Ca}$. P. trifolii'. The fact that very closely related ' $\mathrm{Ca}$. Phytoplasma trifolii' isolates have been identified in $C$. gigantea and previously in $D$. inoxia, suggests that in nature, these two hostscould have possible epidemiological implications for natural spread of ' $\mathrm{Ca}$. P. trifolii' by suitable vectors, particularly when growing nearby cropping areas. 'Ca. P. trifolii' group has also been reported from India in Withania somnifera (Samad et al., 2006) and
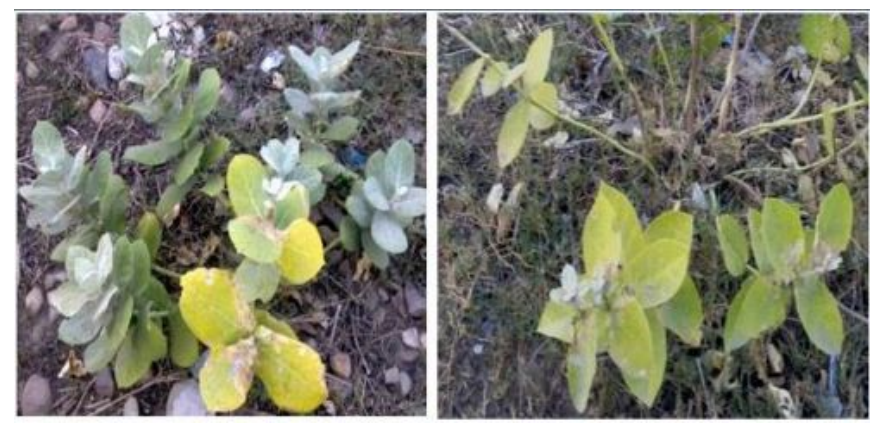

Portulaca grandiflora (Samad et al., 2008). However, the association of 'Ca. P. trifolii' with leaf yellows of $C$. gigantea found in Gorakhpur, Uttar Pradesh, India is a first report.

\section{References}

Ahrens U, Seemüller E, 1992. Detection of DNA of plant pathogenic mycoplasma-like organism by a polymerase chain reaction that amplifies a sequence of the 16S rRNA gene. Phytopathology 82, 828-32.

Deng S, Hiruki C, 1991. Amplification of 16S rRNA genes from culturable and non- culturable mollicutes. J Microbiological Methods14, 53-61.

Gundersen DE, Lee IM, 1996, Ultrasensitive detection of phytoplasmas by nested-PCR assays using two universal primer pairs. Phytopathologica Mediterranea 35, 144-151.

Raj SK, Snehi SK, Kumar S, Khan MS, 2009, First finding of 'Candidatus Phytoplasma trifolii' (16SrVI group) associated with little leaf disease of Datura inoxia in India. Plant Pathology58,791.

[doi:10.1111/j.1365-3059.2009.02053.x]

Samad A, Ajaykumar PV, Shasany AK, Gupta MK, Alam M, Rastogi S, 2008. Occurrence of a clover proliferation (16SrVI) group phytoplasma associated with little leaf disease of Portulaca grandiflora in India. Plant Disease 92, 832. [doi:10.1094/PDIS-92-5-0832A]

Samad A, Shasany AK, Gupta S, Ajayakuar PV, Darokar MP, Khanuja SPS, 2006. First report of a 16SrVI group phytoplasma associated with witches'-broom disease on Withania somnifera. Plant Disease 90, 248. [doi:10.1094/PD-90-0248A]

Figure 1

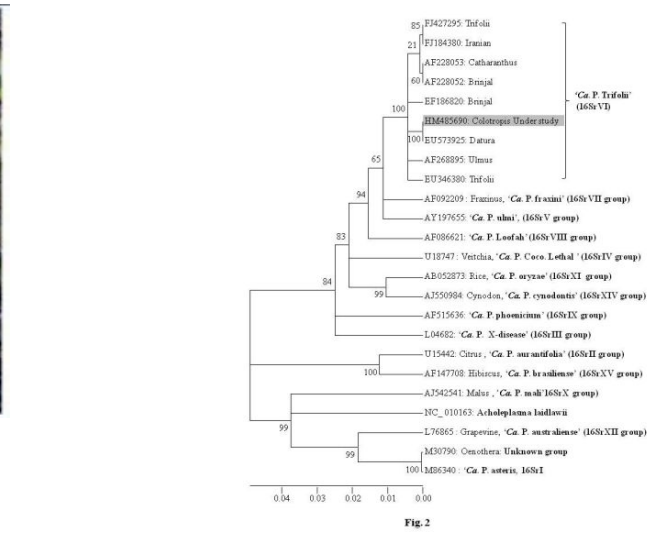

Figure 2

To cite this report: Priya M, Chaturvedi Y, Rao GP, Raj SK, 2010. First report of phytoplasma 'Candidatus Phytoplasma trifolii' (16Sr VI) group associated with leaf yellows of Calotropis gigantea in India. New Disease Reports 22, 29. [doi:10.5197/j.2044-0588.2010.022.029] (c) 2010 The Authors This report was published on-line at www.ndrs.org.uk where high quality versions of the figures can be found. 